\title{
Actuación y desventura de D. Domingo Uriarte Argüelles, Procurador General del Principado de Asturias y Embajador de S. M. D. Felipe V en la Corte de Roma *
}

\author{
por JUAN URIA RIU \\ Catedrático Jubilado de la Universidad de Oviedo
}

Las escasas noticias hasta ahora conocidas de este personaje, proceden casi todas de unas breves líneas que don Carlos González Posada le dedicó en los apuntes manuscritos e inéditos que habían de completar sus Memorias Históricas del Principado. En ellos dice este escritor, que según le había manifestado don José Ruenes, Secretario del Duque de Alba, Uriarte Argüelles había sido Agente del Rey en Roma, y que aunque había obtenido una capitanía, al cabo de sus días, murió infeliz. A estas noticias solo añade las de su nacimiento en Oviedo, que fue abo. gado, al parecer residente en Madrid, y autor de un papel impreso - al

\footnotetext{
* El texto de esta comunicación es una refundición con numerosas adiciones del que lel en el Symposio dedicado al P. Feijoo en Septiembre de 1964, al incorporar posteriormente nuevos datos, obtenidos en el Archivo del Ministerio de Asuntos Exteriores, de los papeles que alli se conservan procedentes de la Embajada de España en Roma cerca de la Santa Sede.
} 
que más adelante hemos de referirnos- con una alegación contra el establecimiento de la Real Audiencia del Principado ${ }^{1}$. Aún son más escuetas las noticias contenidas en las contadas obras que, aparte de la mencionada, hacen alguna referencia a este personaje.

La mera casualidad de sernos familiares los papeles del Archivo de la casa de Meres con la que Uriarte tenía un lejano parentesco por su abuela materna, y de hallarse entre ellos algunos a él relativos, acuaciaron nuestra curiosidad y procuramos indagar lo que pudimos sobre su vida y andanzas redactando esta comunicación.

Ciertamente reconocemos que su valor es meramente anecdótico, y que su persona dista mucho de ser comparable a otros hijos de Asturias que con otros méritos merecen la calificación de ilustres. No obstante, por la parte que las actuaciones de este personaje tuvieron durante varios años en los negocios de la Junta General del Principado, y por las ocurrencias durante su breve etapa de Agente diplomático en la Corte de Roma, tanto como por sus singulares genio y carácter, y su fin desgraciado, creemos puede tener algún interés lo que en esta comunicación decimos sobre él. La historia también la forman las figuras de mediano relieve y aún las mediocres.

Don Domingo Uriarte Argüelles era hijo de Julián Uriarte (quien lo era a su vez de un Juan Uriarte, natural de la provincia de Vizcaya), y había sido Alcalde de los hijosdalgo y de la Santa Hermandad del concejo de Gijón. El lugar de vecindad de la familia fue el de Ruedes en el propio concejo ${ }^{2}$, por lo menos durante algunos años, y allí poseían casas y bienes los Uriarte. La madre, María de la Puerta, era natural de la parroquia de Limanes próxima a Oviedo, e hija de Francisco de la Puerta y de Catalina Gutiérrez Argüelles, ambos vecinos del lugar de Mieres de Limanes ${ }^{3}$.

Ya viuda, la madre de don Domingo figura como vecina de la ciudad de Oviedo, viviendo en la calle y feligresía de la Corte con sus hijos Domingo Antonio (éste ausente) y José, en el año de $1722^{4}$, pero ignora-

1. Biblioteca de la Universidad de Oviedo. Manuscrito núm. 103, pág. 69.

2. Información hecha en Oviedo a 29 de julio del año 1708 por el P. Maestro del convento de San Vicente, Fr. Bartolomé Iglesias, de la limpieza de sangre del aspirante José Uriarte, hijo de Julián de Uriarte y de María de la Puerta (en el Archivo de la Casa de Meres)

3. Ibidem.

4. Padrón del Archivo del Ayuntamiento de Oviedo correspondiente al año 1722, donde María de la Puerta figura con la denominación de viuda de Julián de Duarte, sin duda por errort en vez de Uriarte. 
mos el lugar de nacimiento de éstos, aunque del primero se ha afirmado que había nacido en Oviedo ${ }^{5}$.

Fueron pues vecinos del ilustre P. Feijoo, y aún pudiera haber sido don Domingo alumno suyo en la Universidad donde suponemos habrá hecho sus estudios ${ }^{6}$. Sus dos hermanos, Fr. Alejandro Antonio y Fr. Santiago, fueron monjes benedictinos, el primero en Sahagún y el segundo en Silos, ${ }^{7}$ y probablemente habrán recibido enseñanzas de dicho Padre en el Monasterio de Oviedo.

La época en que nuestro personaje vivió cae dentro de lo que podríamos llamar de la inflación nobiliaria, singular fenómeno social del barroco español, que en Asturias, montañas de Santander y País Vasco, llegó a la mayor exageración. Entre otras cosas era relativamente corriente en aquella época $-\mathrm{y}$ en cierto modo lo fue en todos los tiempos- el afán inmoderado de extraer entre los antecesores de una familia, el apellido que les parecía más ilustre de los varios llevados por sus antepasados, para anteponerlo como la cosa más natural del mundo a otros mucho más directos o inmediatos. Esto llevó a don Domingo a apellidarse primero Uriarte Argüelles, aunque el segundo de estos apellidos no le correspondía tal vez hasta el octavo lugar, y más tarde, cuando se estableció como Agente diplomático en la Corte pontificia de Roma, prescindiendo del Uriarte se apropió en primer lugar el Argüelles.

De diferentes documentos deducimos que sus padres poseían tierras y casas en los concejos de Gijón y Oviedo, bienes que en su mayor parte recayeron en nuestro personaje, pues habiendo renunciado a sus legítimas los hijos monjes, la madre dejó al segundogénito José Antonio los bienes no vinculados más los créditos que hubiese a su favor, y la mayor parte de las propiedades al mayor, que era don Domingo ${ }^{8}$.

La falta de datos cronológicos nos impide conocer la fecha de su nacimiento, que suponemos habrá tenido lugar en los últimos decenios del siglo XVII, desconociendo también la época y el lugar donde hizo sus estudios de Derecho, que suponemos sería en Oviedo. El hecho de figurar como ausente de esta ciudad en los empadronamientos del año

5. Así lo afirma C. González Posada en el MS. citado en la nota (1).

6. Siendo como eran vecinos de Oviedo los familiares de está familia, como vemos por el padrón citado, es posible que don Domingo haya cursado estudios en su Universidad.

7. Consta de la información citada en la nota (2).

8. Archivo de Protocolos notariales de Oviedo, Leg. núm. 918, folios 130 recto al 131 vuelto inclusive. Fue otorgado en Oviedo ante el escribano de la ciudad José Menéndez Valdés, en 12 de junio de 1724. 
1722, nos lleva a pensar que se hallaría ya en Madrid, donde pocos años después sabemos con seguridad que residía. Según esto podemos suponer que iniciaría sus estudios universitarios en los primeros años del siglo XVIII, y aún podría ocurrir que hubiera sido discípulo del $P$. Feijoo ${ }^{9}$.

De su formación universitaria y de su saber, cabe pensar que sin ser un jurista distinguido no fuese tampoco un estudioso adocenado. El alegato contra el establecimiento de la Audiencia de Oviedo, publicado con su firma, revela conocimientos y erudición, y de los elogios que sus corresponsales hacen de sus actuaciones como Procurador de la Junta General del Principado cerca del Gobierno de Madrid, le acreditan de persona activa y conocedora de los negocios que se le encomendaban. Otro tanto parecen reflejar las cartas oficiales que desde Roma dirigió al Ministro de Estado, Marqués de la Paz, que publicamos en el apéndice.

\section{Uriarte, procurador de la Junta General del Principado ${ }^{10}$}

Esta institución, parecida a la Junta de Vizcaya, consistía en una Asamblea formada con los representantes nombrados por los diferentes concejos del país, y algunos otros que representaban las jurisdicciones episcopales (llamadas obispalías) y los señoríos laicos. Su origen se remontaba a la Edad Media, y en ella se deliberaba y se tomaban acuerdos sobre muy diversos asuntos relativos a la administración y economía de la región: repartimientos de tributos, tasas de las mercancías, construcción y reparo de caminos, y demás obras públicas, levas o reclutamientos de soldados, y otros.

Los representantes que asistían a las Juntas recibían el nombre de Procuradores, siendo nombrados dos por cada concejo, con derecho a medio voto cada uno, y teniendo el voto completo uno solo cuando el otro no asistía. Desde 1594 se dispuso que cada voto de una obispalía

9. El P. Feijuo tomó posesión de la cáteclra de Santo Tomás de la Universidad de Oviedo en 7 de narzo de 1710 , siendo posible que por esta época se hallase estudiando en ella don Domingo, aunque no podemos asegurarlo.

10. Sobre esta institución v. Memoria Histórica sobre la Junla General del Principado de Asturias publicada por orden de la misma. Oviedo, Imprenta del Principado, 1834 (intervinieron en su redacción entre otros don José María Caveda y Nava). Más completa es la tesis doctoral de Miguel de la Villa García: La Junla General del Principado de Asturias, Oviedo, Imp. E. Uría, 1909. 


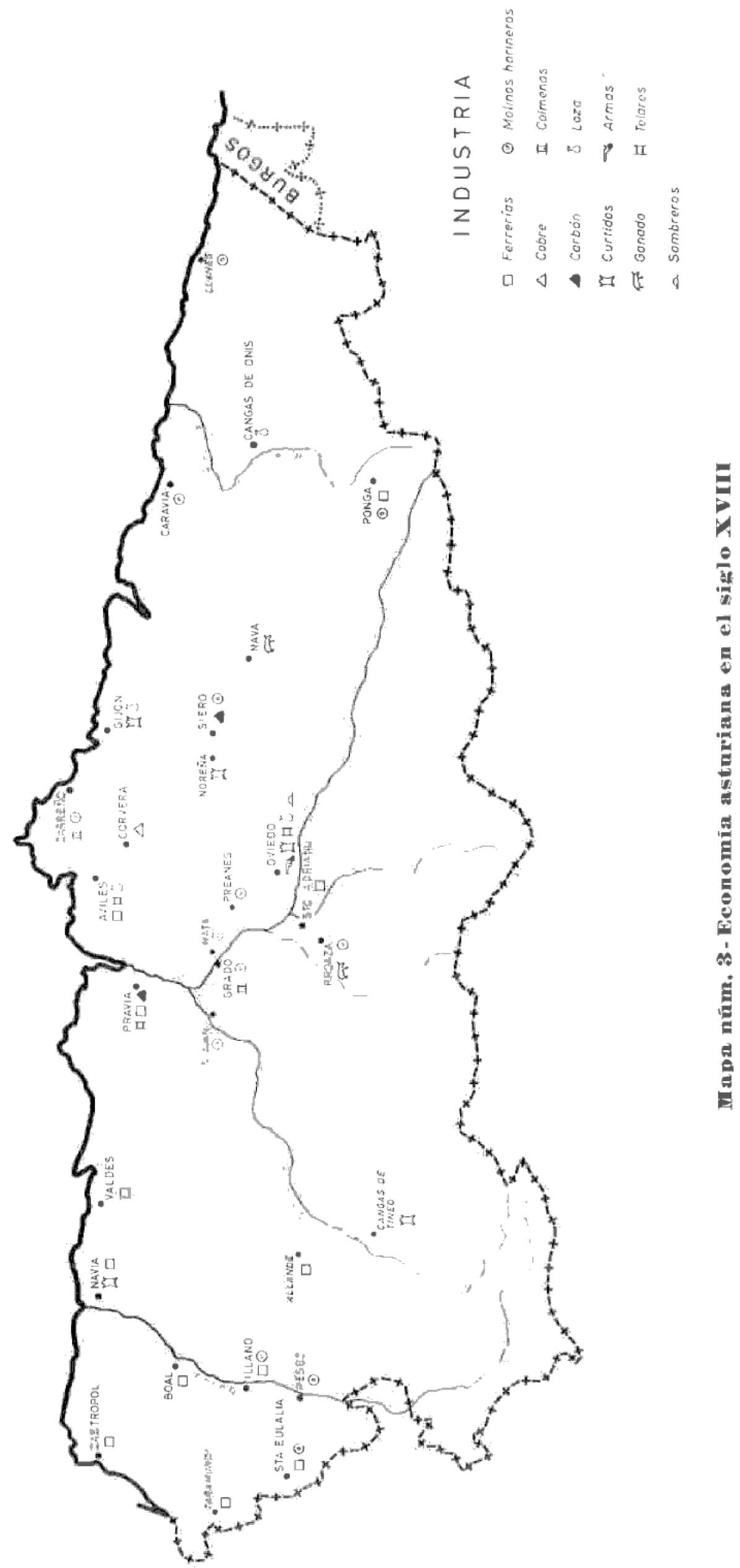


valiera solamente la tercera parte de lo que valía el de un concejo de realengo.

Además de la Junta General, existía la llamada Diputación de dicha Junta, formada por cuatro individuos elegidos por sorteo entre ocho procuradores, los que a su vez elegía la Junta por mayoría de votos. Pero en 1649, el Gobernador del Principado, don Lorenzo Santos San Pedro, modificó el sistema, distribuyendo los concejos en seis partidos cada uno de los cuales había de nombrar un diputado.

Los diputados estaban obligados a prestar juramento de cumplir fielmente sus deberes, y la Diputación tenía las mismas atribuciones que la Junta General, a no ser que se tratase de asuntos de carácter grave o muy importante.

Con las Ordenanzas dadas por el Corregidor don Duarte de Acuña en 1594, se creó el cargo de Procurador General del Principado, que se elegía por turno entre los Procuradores de los partidos o concejos, en la primera de las tres sesiones que por lo menos debía celebrar anualmente la Junta. Dicho Procurador asistía a las Juntas Generales y Particulares, e informaba sobre las cuestiones objeto de deliberación, dando su parecer, pero no tenía voto.

Como enlace eficaz con el Gobierno Central de la nación, y para mejor atender a las consultas y comisiones que se le confiaban, había un procurador general que residía en Madrid, que estaba encargado de ellas. No sabemos de cuando databa esta costumbre, pero sí que en el siglo XVIII ya existía, y que en el tercer decenio de dicho siglo ostentó este cargo don Domingo Uriarte.

\section{Alegación de Uriarte contra la institución de la Real Audiencia de Oviedo}

Aunque impreso en 24 de septiembre de 1724, este alegato es casi desconocido y constituye hoy una rareza bibliográfica. ${ }^{11}$ Nosotros hemos

11. Domingo Uriarte Argüelles: Dictamen Jurídico en Favor det Principado de Asturias, Madrid, 1724, en folio, de 52 hojas. C. González Posada en el Ms. citado en la nota (1) dice que aunque este dictamen kparece declamatorio tiene mucha erudición, y el autor es algo libre, y afecta el estilo siguiendo 
consultado el ejemplar que poseen los descendientes del que fue Rector de la Universidad ovetense a mediados del siglo pasado, don Francisco Díaz Ordóñez.

En él, su autor nos dice, entre otras cosas, que el Principado de Asturias se mantuvo en una paz universal heredada de sus mayores, sirviendo a Su Magestad los asturianos como nobles vasallos, lo mismo en las contribuciones ordinarias que en las extraordinarias, hasta el año 1712, en el que echó raíces la cizaña, el venenoso grano de la Audiencia. Hallábase --prosigue- cumpliendo estos servicios el Principado, cuando el caviloso genio de algunos paisanos (que no pasaron de tres los sediciosos) mal contentos con su suerte, émulos de sus vecinos (a quien tienen por contrarios, no más que por haber heredado más bienes que sus abuelos) comenzó a incitar la venganza para mejorar de fortuna por medio de sus designios, infiel arbitrio - termina diciendo- pero tan antiguo, que ha llegado a ser costumbre en cualquier pueblo pobre.

Se inventó por entonces - dice enseguida- la especie de que los ricos, a los que llamaban caciques, usurpaban el Real patrimonio del Principado, pues éste había sido instituido como un vínculo para el Príncipe por el Rey Don Juan I de Castilla, y por consiguiente eran nulos y usurpados cuantos señoríos jurisdiccionales había en la provincia, y algunas propiedades. Se instruyó por don Antonio José de Cepeda, principal promotor del establecimiento de la Real Audiencia de Asturias y luego su primer Regente, un expediente del que resultó no existir semejante vínculo, ser antiguos los derechos de las jurisdicciones privadas, y legales, puesto que no fueron derogados por ley alguna.

Inclinado a la forma tradicional de ejercer la justicia en el Principado, Uriarte afirmaba que la institución de un solo ministro togado para su gobierno había llegado a ser ley fundamental en esta provincia.

Pensando en una reforma de la justicia, se había llegado a acordar que en Oviedo se estableciese una Junta que conociese en las causas y casos de pesquisa sin mezclarse en la jurisdicción ordinaria, pero esta providencia, que hubiera sido justa, no les convenía a los innovadores, que decían sería costosa, considerando más seguro establecer una Au-

el que prevalecía en aquel tiempon. M. Sangrador y Vitores Historiu de la Administracion de lu Justicia en el Principado de Asturias, Oviedo, 1879, pág. 175 y nota (1), llama a su autor Benito Argíelles equvocadamente, y desestima las razones aducidas por él en contra dis estabiecimiento do la Audiencia de la que Sangrador era Teniente Fiscal, calificando de repicariahts vilgoridades algunas que copia entre comillas. Ciertamente que son duras algunas de sus expresiones, pero la cuestión de la creación de la Audiencia despertó exagerados apasionamientos tanto en pro como en contra de su tiempo, y desde luego fueron absurdos muchos de los manejos de don Antonio de Cepeda, su principal promotor. 
diencia como la de Galicia, que encargada también de la jurisdicción ordinaria atendiese a todo. La pluralidad de jurisdicciones - a la que más adelante hemos de referirnos- embarazaba la marcha de la justicia, y teniendo el Principado medios para mantener la Audiencia, se libraba a los litigantes de los gastos que pudiera ocasionarles la junta.

Otras muchas razones esgrimía Uriarte en su escrito. En la Audiencia no se trataban más que los casos regulares que pudiera evacuar un solo ministro, como lo hacía el Corregidor en tiempos de mayor opulencia, y sobrándole algunas horas.

Un precedente se señalaba también: En 1697 se había dictado un Auto Acordado en el que se ordenaba que no se admitiese caso de Corte que no viniese informado por el gobernador de Oviedo, pues la experiencia había enseñado, que después de muchos gastos en testimonios y probanzas y procesos no se hallaba cuerpo en los delitos, sino ligerezas, efectos de la ira, de la saña o de la incuria. Esto significaba que con el establecimiento de una Audiencia el afán de los pleitos iba a multiplicarse con daño de todos.

Otro inconveniente señalaba también Uriarte: la Audiencia iba a resultar cara, teniendo que pagarla la provincia. Los salarios de sus ministros importaban 6.500 ducados, lo que contrastaba con la escasa importancia de los pleitos en Asturias.

En 1627 hubo ya cierto movimiento en pro de la creación de una Audiencia, pero el monarca envió a don Juan de Chumacero, sujeto recto y justo, que estuvo en Asturias informándose suficientemente, y comunicó que no era conveniente ni necesaria en aquella provincia, bastando allí para el ejercicio de la justicia un solo ministro togado.

En fin, dos años después de establecida la Audiencia, el diputado de la Junta General don Felipe de Caso, se desengañó, viendo su inutilidad para el Rey y la cosa pública, y el diputado por el Cabildo, don Andrés de Llanes Estrada, representó contra ella pidiendo al monarca su reforma. Solamente tres o cuatro concejos de la parte próxima a Galicia eran los que pedían su establecimiento.

Pero si el movimiento de los numerosos expedientes y pleitos que se desató con las providencias de Cepeda no justificaba la creación de un tribunal de justicia como la Real Audiencia por él aconsejada, hemos de reconocer que existían algunas razones para realizar algún género de reforma, que en vano intentó desechar Uriarte en su alegato.

Eran bien sabidas, y por desgraciada experiencia, en el Consejo de 
Castilla ante el que se presentaban las apelaciones en las causas civiles y criminales, las enormes dificultades existentes para conseguir la ejecución de las sentencias, a causa de la pluralidad de jurisdicciones que existían en el Principado, y de la configuración de su relieve cruzado por montañas, ríos y valles, en los que los delincuentes encontraban casi siempre fácil y hasta seguro amparo.

Como los oficiales de la justicia no podían actuar más que en los territorios de realengo, es decir, donde no existía la jurisdicción privada, los criminales y los rebeldes a la autoridad estatal, huian a refugiarse en estos cotos jurisdiccionales, y de uno en otro iban a veces burlando la acción de la justicia con indignación de los agraviados y escarnio de la autoridad. Ciertamente que podían actuar en estos cotos, pero antes necesitaban una autorización, lo que alargaba sobremanera las actuaciones de la justicia.

En el Registro del Sello de Carlos I, que se custodia en el Archivo General de Simancas, hemos leído más de un centenar de Reales provisiones, en las que se contienen hechos verdaderamente sorprendentes y que dan una idea clara de lo carísima que debía resultar la ejecución de la justicia, y de la escandalosa impunidad en que vivían los malhechores. Con estos hechos se podría escribir una antología, especie de crónica negra del Principado de Asturias.

Con la institución de la Real Audiencia se estableció cierta tirantez de relaciones entre ella y la Junta General, que siendo instituciones que podían sufrir interferencias mutuas, no eran sin embargo incompatibles. Lo que ocurrió en la época de su creación fue que los Procuradores que formaban la Diputación, entre los que había que destacar la actuación de personas dotadas de cierta cultura y aptitudes para el mando político, existía un gran recelo de que fuesen mermadas sus atribuciones, como efectivamente lo fueron algunas.

No podemos detenernos a explicar en qué consistían y cómo se fueron reduciendo.

Algo hemos de ver a este respecto, al tratar ahora de la actuación de Uriarte en relación con la Junta General del Principado. Pero tenemos que hacerlo por vía de ejemplos, limitándonos a determinadas cuestiones por no alargar demasiado el contenido de la presente comunicación.

Don José Heredia, uno de los diputados de la Junta, persona acaudalada y principal en la provincia, escribia en 18 de enero de 1727 a don 
Domingo Uriarte que se hallaba en la corte gestionando asuntos de la Junta, muy desilusionado respecto de la objetividad con que ellos eran tratados por los altos poderes estatales, descubriendo la tirantez de relaciones en que la Junta se mantenía frente a la nueva institución. "Todo se debe - dice Heredia en la aludida carta - al amaño y aprecio que los Ministros de su Magestad hacen de vuestra merced condoliéndonos yo y mis compañeros por la fatal constitución en que nos hallamos con esta Audiencia, atados para no poder lo que quisiéramos y es tan justo y debido». (Archivo de la casa de Meres). Se trataba de una leva de soldados que era una de las cuestiones que a la Junta solía suscitar más inconvenientes y desagradables consecuencias.

\section{Levas de soldados}

En las levas forzosas, la administración central quería incluir a los hidalgos contra el privilegio que éstos tenían, y se consideraba defraudada si solo se reclutaban los pecheros. Pero la realidad era que en Asturias aquellos eran numerosísimos y los pecheros escasos, y por si esta escasez fuese poco acusada, gran parte de los pecheros solía emigrar fuera de la provincia en busca de trabajo, con lo cual prácticamente casi no existían pecheros en algunas comarcas de Asturias.

Estas cuestiones eran las que daban lugar a grandes debates entre la Junta y la Audiencia en este momento, en el que llegó a intervenir castigando a los reclutas que se resistían a la leva. La Junta tomó el partido de su defensa, y la carta de Heredia a Uriarte que estamos comentando, lo mismo que las de otros diputados, traslucen sus quejas por la manera rígida de obrar de la nueva institución.

La querella había durado varios meses, pues en 7 de diciembre del año anterior, otro diputado, don José Antonio de Peón, escribía sobre el mismo asunto a Uriarte diciéndole que estaba: «todo el país gimiendo contra la leva de 330 soldados», que inquietaban y costaban mucho, (Arch. de Meres).

El Regente - continuaba- había resuelto conmutar este servicio a dinero, como se había hecho en tiempo de Cepeda, y así hubo de acordarlo la Diputación. Le recuerda luego en la misma carta que tenía una Real Cédula de exención de quintas y levas forzosas para el Regimiento 
con el que el Principado sirvió al monarca en 1702, y que, estando los hidalgos exentos según la práctica de todo el reino, eran impracticables las quintas, porque eran poquísimos los pecheros. Por estas razones se habían ajustado a cinco pesos por soldado, e instaba a Uriarte que si fuera preciso extenderse hasta dos doblones o algo más debería ajustarlo, pues la Diputación lo aprobaría; mas no había que perder tiempo, pues habían prendido cincuenta soldados y hecho extorsiones, y los que estaban presos gritaban diariamente.

Sin alargarnos a tratar de otras incidencias y consideraciones sobre esta cuestión, diremos que Uriarte consiguió la suelta de algunos presos y el indulto de otros, y en diferentes cartas los diputados elogian su actividad y los buenos resultados de sus gestiones con los altos poderes.

\section{Régimen de Aduanas}

Cuestión de gran interés para el Principado era la del régimen que se aplicaba al funcionamiento de las Aduanas. La Junta ,por mediación de don Domingo Uriarte, se dirigió a Su Majestad para que se sirviese mandar que las Aduanas se restituyesen a los puertos secos, como se había hecho en Vizcaya y las cuatro villas de la Montaña, porque habiéndose puesto en Asturias a la lengua de la agua -dice la representación dirigida por don Domingo- por las razones que se pusieron en otras provincias, debían también quitarse por las mismas razones. Mayormente - se añadía - cuando Asturias era la capital provincia de la Cantabria, y la primera de la monarquía, más pobre, y por ello más digna de que su Majestad le hiciese aquella gracia que tenía su fundamento en preceptos de justicia.

El razonamiento sobre estos fundamentos se encuentra en una minuta en simple existente entre los papeles que pertenecieron a Uriarte y existen en el archivo de la casa de Meres.

Se dice en ella que el diez por ciento de las mercancías que se traen de fuera a los puertos del reino, lo mismo que el de las que se exportan desde ellos, cantidad que antiguamente se cobraba en las Aduanas, se ha convertido en el quince. Se agrega que del primer establecimiento que de ellas se hizo, fueron exceptuados y francos los puertos del Norte 
de España, siendo situadas en cambio en los puertos secos que se hallan en las gargantas de las montañas y a las salidas de las tierras llanas y abundantes, porque conociendo la esterilidad de aquel terreno, fragoso, escaso de frutos y abundante de pobladores, se les dejó a éstos franco comercio, porque, ayudados de la industria, pudiesen enmendar la escasez de la naturaleza, buscando el intercambio de los frutos que se pueden llamar inútiles, como avellana, nuez, limón, naranja y maderas, por otros más necesarios para su conservación y subsistencia, como son el vino, el aceite y géneros de vestir, de todos los cuales carece enteramente. Con este sistema, según el informe que vamos siguiendo, había logrado el Rey no solo la conservación de aquellas pobres provincias, sino la más cómoda administración de sus rentas, por que siendo tan vasta la extensión de las costas de Cantabria y Galicia, con tanto número de puertos y caletas, no se podían evitar los fraudes, especialmente en el verano, en el que, a favor de la bonanza, se podía abordar a cada peña, sin excesivo número de guardias a caballo, que consumían una buena parte de la renta, y no atajaban el daño. En cambio en las gargantas de los puertos secos se aseguraban con poca vigilancia, porque las peñas inaccesibles que circundaban aquellas provincias, dejaban pocas vías de paso seguras, y tan estrechas, que se habían guardado siempre con facilidad.

Como sabemos, estas circunstancias se dan especialmente en Asturias con características más acentuadas que en el resto de la región cántabro-astur-galaica.

Todo esto que va dicho -continúa refiriendo la minuta- lo ha acreditado la experiencia, porque aunque en la nueva providencia del año 1717 se extendieron estas contribuciones a todas las provincias exentas, no habiendo crecido en la universal del reino el producto cle esta renta, antes bien «se tiene entendido que en los primeros años tuvo mucha quiebra, y en los sucesivos poca utilidad, lo que no se puede especificar, porque los administradores y los asentistas callan misteriosamente los valores por sus particulares intereses».

Tales eran los asuntos encomendados a don Domingo como Procurador General de la Junta del Principado, aparte de otros que renunciamos a tratar por no dilatar esta parte y porque creemos suficientes por vía de ejemplo los que acabamos de comentar. 


\section{Uriarte, Agente general de Felipe $\mathrm{V}$ en la Corte Pontificia de Roma}

La primera observación que hemos de hacer respecto de esta etapa de la vida de don Domingo, es la del abandono del apellido Uriarte por el de Argüelles con el que se denomina en el título de Agente del Rey en Roma, y con el que en adelante firma sus cartas.

La obtención de este cargo debió alcanzarla en ocasión que como Procurador de la Junta del Principado hubo de mantener durante algunos años relaciones y trato con los principales funcionarios de los departamentos ministeriales, con los ministros y con el propio Patiño, el más destacado de todos. Es probable que él haya sido quien le propuso para desempeñar el cargo de Agente General y procurador en la Corte de Roma de los Negocios de los Reinos de Castilla, de las Indias y Cruzada, aunque su superior inmediato en este cargo haya sido don Juan Bautista de Orendain, marqués de la $\mathrm{Paz}^{12}$.

Como tal Agente, don Domingo se hallaba a las órdenes del Ministro Plenipotenciario de España cerca de la Santa Sede, Cardenal Bentivoglio, que era el verdadero embajador.

En el nombramiento de Argüelles —como en adelante llamaremos a Uriarte- se señalaba el sueldo anual de 24.000 reales pagaderos por el Director de la Posta de España en Roma, y se expresaba que su duración sería la que señalase la voluntad de Su Majestad.

Algún tiempo antes de aceptar el cargo, Argüelles debió comunicarlo a sus amistades y entre ellas a su lejano pariente don Lope José de Argüelles quien en carta que se conserva le advierte la conveniencia de meditar bien la cuestión de su nuevo rumbo vital. Pero don Domingo debió imaginar colmadas sus ambiciones con el apetecido cargo que al fin significaba un puesto de alguna importancia al servicio del rey.

Todavía en aquella época debía tener curso aquel adagio expresivo de las tres maneras deseables de escoger medios de vida para los españoles: Iglesia, Mar o Casa Real.

Movido por sus sentimientos optimistas levantó su casa de Madrid, vendió los muebles y la biblioteca, y salió para Italia en la primavera

12. El título original de este numbramiento se halla en ei archivo de la Casa de Meres y fue otorgado en Madrid a 8 de enero del año 1728. 
del año 1728. Además del título de su cargo llevaba otro de los que entonces se estimaban mucho y más particularmente en los medios cortesanos y diplomáticos, el de Marqués de la Paranza, que habiendo sido concedido en 1698 al Presidente del Consejo de Castilla, don Antonio de Argüelles de Meres por Carlos II, fue heredado por su sobrino don Lope José y renunciado por éste en favor de don Domingo ${ }^{13}$.

El 20 de marzo de 1728 el Cardenal Bentivoglio, ministro plenipotenciario de España cerca de la Santa Sede, escribía al Ministro de Estado Marqués de la Paz, acusando recibo de su carta del 15 de enero, en la que le daba cuenta del nombramiento de Agente General y Procurador en la corte pontificia de don Domingo Arguielles, que había de servir dichos empleos como los había servido don Juan Antonio Díaz de Arce, bajo las órdenes del cardenal y enteramente dependiente de ellas (aunque estas palabras subrayadas no constaban en el nombramiento ${ }^{14}$. Transcurrido poco más de un mes volvió a escribir el cardenal al marqués de la Paz, anunciándole que el lunes 26 de abril había llegado a aquella corte don Domingo, quedando hospedado en el Real Palacio [de España], mientras encontraba casa de su satisfacción. El Agente había puesto en sus manos el Real Despacho con el nombramiento y Bentivoglio manifestaba le daría cumplimiento, presentando al Papa y a sus ministros el recién nombrado, para que le conocieran como tal Agente, agregando que se valdría de su persona en lo relativo al Real servicio ${ }^{15}$.

Algún tiempo después, el cardenal volvió a escribir al ministro español manifestándole que don Domingo le había expuesto que el sueldo que se le había asignado era insuficiente para la decencia que correspondía a su empleo, y a la que mantuvieron sus antecesores. A esto agregaba el cardenal que habiéndose informado, había sabido que verdaderamente aquellos se habían portado con toda decencia, y que, el nuevo Agente no podría hacerla con los 400 anuales que percibía. Terminaba la carta diciendo que le había parecido complacer a aquel caballero pasan-

13. Don Lope José de Argüelles, a poco de la muerte de su tío, solicitó la sucesión en el título a condición de que se le concediese libre del pago de lanzas y media annata, según se le había concedido a aquel. Pero esta pretensión le fue denegada. No obstante haber solicitado al mismo tiempo que de no serle concedida, deseaba que el título fuese incorporado a la corona, ahora nos encontramos con que hizo renuncia de él a nombre de don Domingo, al que reconoce como pariente, y la escritura original de esta renuncia se halla en el Archivo de la Casa de Meres, constando en ella fue otorgada en dicha Casa y ante el escribano Francisco Fernández de Pando en 13 de mayo de 1727. Otra copia se halla en el Archivo Histórico Nacional.

14. Archivo de la Embajada de España cerca de la Santa Sede. Madrid, Ministerio de Estado. Leg. núm. 178, Carta de 20 de marzo de 1728

15. Ibidem Leg. id. Carta de 28 de abril de 1728. 
do a noticia de Su Majestad lo expresado para que se dignase aumentarle el sueldo ${ }^{16}$.

Como se puede ver, hasta aquí, las relaciones entre don Domingo y el cardenal Bentivoglio fueron normales y aún cordiales. Pero pronto surgió un incidente que vino a ser el primero de una serie de discordias que terminaron por predisponer al purpurado en contra de nuestro Agente, al extremo de ser depuesto de su cargo, principalmente a causa de los informes y opinión expresados por aquel en su correspondencia con el ministro de Estado español.

\section{La conducta del Agente disgusta a Bentivoglio}

Fue el caso que cumpliendo órdenes de Su Magestad para la provisión de unos beneficios vacantes por la Dataría pontificia, y recomendado para uno de ellos por el propio monarca un don Agustín Gastea, Bentivoglio, que había prevenido de ello no solo al cardenal Datario sino al mismo Papa, por medio del cardenal Fini, los cuales se inclinaron a complacerle, se encontró con que don Domingo, al tener noticia de aquellas vacantes se fue a ver al cardenal Datario, y como éste le refiriese que ya Su Santidad se hallaba prevenido en favor de otro sujeto, pasó entonces al Vaticano a pedirle audiencia y no habiéndola conseguido suplicó a Monseñor Borghe, Secretario de Cámara del Papa, entregase a éste un memorial, lo que en efecto realizó, siéndole concedida por Su Santidad la gracia; de manera que el hermano de Arguielles, José Antonio, consiguió el beneficio de Carmona de la diócesis de Sevilla, que era de los mejores, mientras que el recomendado del monarca, Gastea, solo consiguió el de la puebla de Coria, de la misma diócesis, pero que no llegaba a los 10.000 reales de renta anual ${ }^{17}$.

En la carta en que daba cuenta de todo esto, Bentivoglio decía al Marqués de la Paz, que debía de haber merecido mayor reflexión y atención la premura de Su Majestad por un sujeto - Gastea- que, además de sus óptimas costumbres, tenía ya diez años de Curia. Además, Argüelles había venido a decirle que no había hecho nada por conseguir su preten-

16. Ibidem Leg. id. Carta de 1 de agosto de 1728.

17. Ibidem Leg. id Carta de 4 de setiembre de 1728, 
sión, y había recibido la gracia de Su Santidad sin habérsela pedido, pero a Bentivoglio le constaba lo contrario y por lo tanto no había podido excusar el desaprobarle lo que había hecho, agregando que de todo esto podía ver el marqués la poca o ninguna verdad con que procedía aquel hombre. Aún se alargaba en otras consideraciones afirmando que no consideraba conveniente que el Agente buscase beneficios del Papa para sus parientes al principio de su entrada en Roma, y advertía que la facilidad con que Su Santidad había favorecido a don Domingo, suscitaba en él la sospecha de que la corte pontificia quisiera ganarlo de esta manera, como había sucedido en otros tiempos en casos análogos. La carta de Bentivoglio terminaba diciendo, que ante el temor de que don Domingo continuase pidiendo audiencias de esta forma, a pesar de sus advertencias, y beneficios en Dataría para sus ahijados ocultándole la verdad, rogaba al Ministro español que tuviese en cuenta lo expresado, para hacer el uso que su gran prudencia estimara conveniente, añadiendo que le parecía justo que cuando él pidiese alguna gracia a Su Santidad en nombre del Rey, Argüelles debía de ayudarle a conseguirla y no procurar embarazarla.

Las acusaciones que la carta contenía no podían ser más contundentes, ni el juicio adverso sobre la conducta del Agente más terminante. Sobre la gran audacia de Argüelles en este trance no puede existir duda alguna. Lo extraño es su conducta posterior, negando haber hecho algo por conseguir el beneficio en favor de su hermano. El acto podía calificarse de un abuso reprochable; pero en fin de cuentas no constituía ningún delito, y buena prueba de ello es que el rey no le impuso sanción alguna.

Lo que sí se trasluce en la carta de Bentivoglio es la indignación que aquel acto le produjo, y el pésimo concepto que de Argüelles se formó. A partir de este momento, era natural que la tirantez de relaciones entre el Ministro Plenipotenciario y el Agente haya continuado. No solo ocurrió así, sino que fue aumentando, como se deja ver en su correspondencia con el Marqués de la Paz, en la que veremos abundan noticias de nuevos desaciertos e irregularidades en la conducta de aquél.

Todas estas manifestaciones hacen comprender la escasa consideración que en adelante debió merecer al cardenal la persona del Agente español.

A mediados de diciembre el purpurado se queja al Marqués de la Paz de la manera displicente con que aquél prescindía de su autoridad, no presentándose en su antecámara para recibir en caso de necesidad las 
órdenes convenientes como habían hecho los demás Agentes. Al mismo tiempo manifestaba Bentivoglio su extrañeza de que don Domingo hubiera enviado al Cardenal Cienfuegos - ministro plenipotenciario del Imperio cerca de la Santa Sede- un grueso pliego que suponía fuese dirigido al conde de Kinviseck «lisongeándose con el apoyo de estos dos personajes segundar sus caprichos y executar impunemente los que más le agrade», agregando que, había llegado a sospechar si todos estos pasos no apuntarían al objeto de hacerse llamar «a esa corte con algún empleo y oropel» ya que, dado el abismo de deudas en que se había engolfado por pura vanidad y ligereza, bucsaría así la salida en la ausencia de su persona, para no pagar a sus acreedores..$^{18}$

En carta de mayo, Bentivoglio da cuenta de cierto incidente «tocante al demasiado fervor con que procedió don Domingo Argüelles en la ocasión que de la cercanía de su casa sacó la justicia», con permiso de aquél como autoridad suprema del pequeño distrito autónomo en que se haIlaba emplazada la embajada de España, un coche y dos caballos de una tal Paula Leche. El propio Argüelles se había adelantado a dar cuenta del hecho al Marqués de la Paz, quien ordenó al cardenal le reprendiese severamente ${ }^{19}$.

Con más pormenores se repiten en junio los informes sobre la conducta de don Domingo en este incidente. Y en cuanto a las órdenes de rereprensión, Bentivoglio manifestaba que lo haría en términos generales, pues eran muchos los disparates, locuras y prepotencias $y$ travesuras con las que continuaba haciéndose cada vez más ridículo en aquella corte, y hasta llegaban al cardenal memoriales de sus acreedores, a cuyas reclamaciones contestaba con malos tratamientos y amenazas de palos y otras enormidades ${ }^{20}$. Por complacer a la referida Paula Leche, fueron tales las amenazas, apremios y vejaciones que hizo sufrir a un criado de aquella, que para librarse de ellas, el infeliz se vió obligado a vender sus bienes y marchar de la corte. El cardenal terminaba su información diciendo que lo peor era que no cabía esperanza alguna de enmienda.

Todos estos detalles reveladores de la desastrosa conducta de Argüelles, contrastaron con una exagerada sobrestimación de su persona, pues no contentándose con el título de Marqués de la Paranza, según Bentivoglio se hacía tratar por sus criados de Excelencia.

18. Ibidem Leg. id. Carta de 15 de diciembre de 1728.

19. Ibidem Leg. 179. Carta de 24 de mayo de 1729.

20. Ibidem Leg. id. Carta de 25 de junio de 1729. 
En otra de las cartas, Su Eminencia decía haberse convertido don Domingo en "amante, protector y defensor de Paula Leche», y que después de lo ocurrido ya no se dejaba ver por el Real Palacio como no fuese en los días de fiesta ${ }^{21}$.

Un nuevo incidente vino a agravar la situación de Argüelles con ocasión del embargo de bienes dictado contra el matrimonio Leche, a petición de un sastre con el que se hallaba en deuda. Habiendo obtenido el acreedor una autorización de la justicia para hacer efectivo su cobro, y una licencia de Bentivoglio para que se realizase el embargo dentro de los términos de la jurisdicción de la embajada, sucedieron una serie de escenas escandalosas. Cuando los esbirros pasaron a vías de hecho, don Domingo envió a su Secretario, quien tras de exigirles que le mostrasen la licencia, pasó a la violencia, viéndose uno de los esbirros obligado a echar mano a la pistola. Como el Secretario fuese a quejarse a su amo, éste, a pesar de hallarse a la sazón indispuesto, bajó hasta el portón de la casa que estaba contigua a la suya, al tiempo que pasaban delante de la misma tres esbirros a los que injurió de palabra. Como el que llevaba secuestrados los vestidos de Paula Leche se pusiese en fuga, don Domingo dio orden a sus criados de apalearlos, lo que realizaron quitándoles al mismo tiempo un caballo que también llevaban secuestrado. Uno de los esbirros fue herido en la cabeza a golpes de espada, otro fue apaleado, y un tercero huyó como hemos dicho.

De la reincidencia de don Domingo sin atención alguna a las órdenes dadas por el Marqués de la Paz a través de Bentivoglio, se deducía su incorregibilidad y la apurada situación en que comprometía a la embajada de España con el gobierno de Roma, en contra de los desvelos que el cardenal procuraba para seguir conservando el privilegio de la franquicia jurisdiccional. Por otra parte el gobernador de Roma había enviado una queja de todo lo ocurrido, lo que obligó a Bentivoglio a dar explicaciones a éste y al cardenal Secretario de Estado, y en evitación de mayores males, dio las órdenes oportunas para que el matrimonio Leche saliese de la franquicia jurisdiccional. Sobre todo ello se hallaba en una situación ambigua, pues por una parte no podía dejar de defender a personas que como los criados de don Domingo y su Secretario se hallaban al servicio de un Agente del rey de España, y al mismo tiempo se habría declarado parcial al defenderlos.

El Marqués de la Paz dio cuenta al rey de lo ocurrido, reafirmándose

21. Ibidem Leg. id. Otra carta de 25 de junio distinta de la anterior. 
en su opinión sobre la incapacidad de enmienda del Agente ${ }^{22}$. Todavía insistió Bentivoglio en comunicar más detalles sobre las consecuencias de estos hechos durante los meses de octubre y noviembre ${ }^{23}$. En sus cartas Bentivoglio se refiere a la falacia de Arguielles al negar la ocultación en su propia casa de los criados encartados en estos incidentes, a pesar de las advertencias que recibió en contra.

\section{Argüelles es exonerado de su cargo}

Por último a primeros de enero del año 1730, el Cardenal recibía oficio del Marqués de la Paz, en el que manifestaba haber dado cuenta a Su Majestad de todo lo ocurrido, en vista de lo cual había acordado separar a don Domingo Argiielles del empleo de Agente, cargo para el que le prevenía sería nombrada otra persona ${ }^{24}$. El 31 de enero aún no había salido de Roma don Domingo, pero se esperaba que saldría en breve, quedando entonces cortados todos los inconvenientes que se pudieran derivar de los incidentes referidos ${ }^{25}$.

\section{Su permanencia en Roma después de exonerado}

Poseemos las copias de ocho cartas escritas desde Roma, la primera fechada en 21 de enero de 1730, y la última en 22 de abril de dicho año que nos demuestran que don Domingo Argüelles permaneció por lo menos unos cuatro meses después de anunciada su exoneración por el marqués de la Paz. De ellas, seis fueron escritas a este ministro, las dos restantes al cardenal Belluga. Todas se reproducen en el Apẻndice.

Corresponden pues, al periodo en que España mantenía con el Im. perio cierta tirantez de relaciones. En 9 de noviembre de 1729 se había

22. Ibidem Leg. id. Carta de 2 de agosto de 1729.

23. Ibiclem Leg. id. Carta de 2 de octubre de 1729, y alguna otra posterior

24. Ibidem Leg. 180. Carta de 3 de enero de 1730.

25. Ibidem. Carta de la referida fecha. 
firmado el tratado de Sevilla por el que Francia e Inglaterra autorizaban la ocupación de los ducados de Parma y Plasencia, que había de regir el infante don Carlos con el de Toscana, por las tropas españolas.

En enero del año siguiente, Argüelles escribía al Marqués de la Paz comunicándole su sorpresa de que en aquellas circunstancias concediese el Pontífice a Austria la prórroga de la Décima de los beneficios eclesiásticos en los Estados que el Imperio gozaba en Italia, pues según se publicaba en Roma, se hacían en Austria grandes preparativos para la guerra, y en estas circunstancias la referida concesión parecía como si la corte pontificia comenzase a declararse parcial de la de Viena.

El Cardenal Polignac - agregaba Argüelles- le había dicho que, como amigo del Papa y ministro de un Príncipe aliado del Rey Católico, había manifestado los inconvenientes que esta actitud significaba, para que Su Santidad suspendiese por ahora la expedición de la gracia. El Cardenal Secretario de Estado decía que al serle dada cuenta de esto, el Papa se había excusado, diciendo que no había pensado en este inconveniente ni era su ánimo disgustar al Rey Católico, pero que, habiéndose entregado ya el Breve al ministro imperial, no le quedaba otro arbitrio sin incurrir en mayores inconvenientes.

Continúa diciendo Argüelles que en vista de todo esto, él había acordado con el Cardenal Polignac que éste instase nuevamente al Papa, para que ordenase la redacción de otro Breve, declarando que, en caso de que la corte imperial hiciese la guerra a España, quedase suspendida esta gracia de las Décimas, desde el día en que ella se declarase, porque la Sede Apostólica no podía conceder subsidios a un Príncipe católico contra otro.

Hízolo así el cardenal francés — según dice en la carta Argüellespor medio de otra representación al Secretario de Estado, el cual respondió que estaría atento para dar cuenta al Papa y avisar de su respuesta, pero que. temía mucho que Su Santidad no accediese a aquella proposición. De esto se deducía, según Argüelles, que eran grandes, muy activos y maliciosos los manejos que se hacían por parte de la corte imperial, cuyos ministros dormían con los ojos abiertos aprovechándose del descuido y poca aceptación de nuestro ministro en la Corte pontificia.

Otras noticias comunicaba a su jefe en esta carta relativos a los preparativos que se hacían para las tropas imperiales en los Estados de la Iglesia, a las negociaciones que realizaban los saboyanos, y al municionamiento de las plazas fronterizas con Francia, de donde deducían en 
Roma que las dos Cortes se hallaban de acuerdo en contra del tratado de Sevilla ${ }^{26}$.

En esta situación el papel de España decaía a los ojos de los romanos: «Maiormente - dice Arguielles- cuando no se ve que por nuestra parte se hace paso activo, ni el menor fomento, porque nuestro Ministro Principal (cuyo carácter y constitución tengo explicado) se contenta con el retiro de su casa, pasando la vida en lamentaciones porque no se le paga».

La carta es pesimista, y la conducta negligente del Cardenal Bentivoglio aparece en ella figurada con tintas bien recargadas. Pero no es más optimista lo que atribuye en ella a Monseñor Acquaviva, Mayordomo del Papa, del que afirma se decía que había alcanzado este cargo y el de Maestro de Cámara por su dinero. No quisiera que se lisonjeasen en nuestra Corte con sus oficios, dice, pues nadie le tenía por apropósito para encargarse de nuestros negocios en tiempo tan crítico, ni su inclinación a España tenía más raíces ni otro objeto que el interés propio.

Al final y a manera de postdata, incluye un comentario interesante para el conocimiento del ambiente diplomático de la Corte romana en relación con España. Advierte que ya había ocurrido lo que hacía un mes había anunciado respecto del conde de Almenara y Palma. El emperador había solicitado para éste un capelo por nómina regia, pero esta solicitud la había hecho como Rey de España. La anomalía no podía ser más patente, el Papa vendría a negar el reconocimiento del trono de Su Majestad el Rey don Felipe V. No se trataba de ningún rumor, el hecho era cierto, y lo peor era que a esta iban a seguir otras intentonas, si el monarca español no ponía remedio.

Arguielles dice también que había visitado a este nuevo sacerdote porque le había parecido atención cortesana el hacerlo mientras su superior no mandase otra cosa, porque este caballero y el Cardenal Cienfuegos -otro asturiano que habiendo seguido el bando austriaco era ahora ministro plenipotenciario del Imperio en Roma- eran sus amigos, aunque más amigas fuesen la lealtad, la verdad, y la honra.

En febrero vuelve nuestro personaje a comunicar noticias de interés, comenzando por la de la muerte del Papa Benedicto XIII, ocurrida el martes 21 a las tres de la tarde, a consecuencia de la repetición de una fiebre que había comenzado el sábado anterior a las diez de la noche, según ya había avisado a su ministro por la posta ordinaria.

26. Ibidem. Carta de 21 de enero de 1730. 
Eran muchos los que en aquellos días morían a consecuencia de una epidemia de fiebres que azotaba la ciudad de Roma.

Sobre el cónclave próximo era de esperar que se nombrase un Papa viejo, pues no había partidos ni jefes. No se esperaba que viniesen los cardenales ultramontanos, con excepción de los germanos que andaban por cierto muy circunspectos, cautelosos y solícitos respecto a las cuestiones de Italia desde que comenzaron los rumores de la guerra, y que se había de cuidar en hacer lo posible por atraer a su facción al Papa.

Bentivoglio, siempre con poca salud, estaba ahora retirado, pero podía temerse que, si entrase en cónclave, experimentase algún mayor perjuicio con el cambio de vida, y el trabajo incómodo en aquellas pequeñas estancias, en las que permanecían los cardenales del Cónclave, se hacía más molesto. ${ }^{27}$

Sobre la marcha de los asuntos relativos a la elección del Papa continuó escribiendo Argüielles. Señalaba en carta de 4 de marzo el estado de poca salud de Bentivoglio, sin fuerzas para el intenso trabajo moral a que se hallaba obligado en aquel trance. De ello resultaba que se dejaba aconsejar de personas cuya conducta y mala opinión perjudicaban su ministerio, como experimentaba precisamente en aquellos momentos, pues todos huían de tratarle con confianza. Argüielles creía que se elegiría Papa a despecho suyo, porque no había en el Sacro Colegio a quien no hubiese disgustado, y hasta el Cardenal Polignac se lamentaba de su conducta.

En estos juicios contrarios a Bentivoglio tomaría parte la animadversión con que el Agente tenía que mirar a quien tan directamente había intervenido en los desagradables incidentes ya referidos y que dieron lugar a la exoneración de su cargo.

En la misma carta que comentamos, daba cuenta de haber visto al Cardenal Alberoni, quien le había ratificado su propósito de secundar con su voto e influencias las intenciones del rey Don Felipe, y le había vuelto a referir ciertos incidentes ocurridos con el Cardenal Acquaviva en los cónclaves anteriores, a pesar de los cuales había cumplido su deber en servicio de Su Majestad como lo haría también ahora. Nada sentía tanto - según agregaba Argüelles- como que se dudase de su constancia y se le tuviese por ruin y desagradecido ${ }^{28}$.

Dos de las cartas de Roma escritas por Argüelles están dirigidas, como

27. Ibidem. Carta de 23 de febrero de 1730

28. Ibidem. Carta de 4 de marzo de 1730. 
hemos dicho, al Cardenal Belluga, Obispo de Cartagena y uno de los prelados más notable de España. Este apoyaba al Cardenal Imperiali para la elección de Papa, figurando por lo tanto en el grupo contrario a Bentivoglio, y Argüielles le escribe animándole a seguir la propaganda en su favor y a evitar el veto o exclusiva por parte de España, que a la sazón pregonaba Bentivoglio. También rogaba a Belluga que procurase pactar con el Papa futuro para que interviniese en asegurar la sucesión de Toscana, Parma y Plasencia, evitando que ello nos llevase a una guerra. ${ }^{29}$

Como el veto a Imperiali venía firmado por el Ministro y no por el Rey, los amigos de aquél, instigados especialmente por el Cardenal Belluga, impugnaron su autenticidad. Por último, se consiguió la unanimidad a favor del Cardenal Corsini, al que votaron los 52 Cardenales allí presentes. El elegido tomó el nombre de Clemente XII.

En esta elección -dice Pastor- se vio una obra de la Providencia, por ser elegido Papa un miembro del Sacro Colegio contra el que habían trabajado todas las potencias de la tierra, tan vivamente y tan en vano ${ }^{30}$.

\section{Regreso de don Domingo Argüelles a España $\mathrm{y}$ últimos servicios}

De la correspondencia con el Marqués de la Paz, solamente en la carta de 23 de febrero alude a su exoneración, culpando a los consejeros de Bentivoglio, Saporito, Exabolini y Mauro, de haber impulsado al Cardenal a conspirar a su ruina «sin que yo - dice textualmente- le haia dado la menor causa, como es vien notorio a toda Roma y como reconocerá V. E. si seriamente reflexiona los casos y cosas en que se haya lamentado de mí Su Eminencia, no más que por la simple aprensión en que le han puesto esta gente maligna y codiziosa». Continúa diciendo que se sorprende de que habiéndole alabado en algunos escritos y habiéndole servido con la mayor veneración sin dejar de obedecerle «se haya puesto en una aversión contra mí, que no se contenta con quitarme el empleo, impedir que me pagase el Director de la posta ei atraso de mi sueldo, sino quitarme

29. Ibidem. Carta de 16 de marzo de 1730.

30. Ludovico Pastor, Historia de los Papas, t. XXXIV, Barcelona, G. Gili, 1930, pág. 278. 
también el tratamiento y honores de Agente, e impedirme ahora los frutos de la expedición, que el Rey me consigna por parte de alimentos de su real título, y otras injurias».

Después de lo que sabemos por las cartas de Bentivoglio al Marqués de la Paz, respecto a las incidencias de la vida de Argüelles en Roma, no acertamos a comprender cómo escribió semejantes palabras. Cabe que los consejeros de Bentivoglio hayan conspirado a las denuncias sobre su conducta, y hayan recargado las tintas exagerando los hechos, pero el fondo de la conducta irregular del Agente parece indudable. No es posible admitir la falsedad de todas las acusaciones, aunque tal vez haya existido alguna exageración. Esto, aunque no las justifica, explicaría las palabras que a continuación escribe Argüelles, diciendo no puede comprender "cómo se quite al ministro español el empleo, y la honra; solo por condescender al equivocado concepto del ministro forastero, en que ni aún el mismo tiene más culpa que la de dexarse conducir de estos tres hombres, cuya dañada intención es bien conocida». Continúa suplicando al Marqués de la Paz repare las circunstancias de los hechos, considerando lo que pierde, la repugnancia con que vino a Roma, los gastos de más de dos mil doblones que hizo, la incomodidad del largo viaje en invierno. Le advierte que dejó el cargo de Procurador General del Principado de Asturias que le producía 600 doblones anuales, y era un puesto honrosísimo, que vendió sus libros y los muebles de su casa, que es un hombre con honra, con profesión, y que últimamente sirvió a S. M. sin perder negocio alguno. Insiste en que ya en otras ocasiones le expuso estas consideraciones, pero cree necesario repetirlas "porque aunque yo -añade hubiera tenido alguna parte en el ridículo embarazo de mis criados con los esbirros [del Gobierno de Roma], en que el cardenal me hizo el asesinato y después el proceso, no es causa bastante para deshacer y arruinar un hombre de estas circunstancias, que llegó a este empleo por sus pasos contados, a costa de muchos de estudio, trabaxos y dinero, y que puede llegar a otros maiores, si por la piedad del Rey se digna darle ocasiones».

La carta termina rogando que el ministro haga presente a S. M. se sirva resolver como tiene pedido, para no salir de allí «con deshonor, sin destino propio, sin cobrar el sueldo y emolumentos que tengo servido».

Sin duda no se hizo cargo de la situación que se creó, en parte, por su conducta y en parte acaso, por la intriga de los consejeros de Bentivoglio. No todo lo que andaba entre curiales u oficiales de la curia pontificia era impecable ni mucho menos.

Argüelles volvió a España probablemente a fines del año 1730 o prin- 
cipios de 1731, y no volvemos a saber nada más de él hasta el 20 de mayo del año 1732 en que un amigo llamado José Antonio de Tineo le escribe desde Madrid para hacer llegar la carta, no sabemos si a la prisión de Ceuta a la que fue reducido después de servir al Rey de España, ya vuelto de Roma, en algún puesto de menos categoría del que había perdido.

\section{Argüelles es enviado al presidio de Ceuta}

Sabemos que fue llevado a la prisión de Ceuta por otras cartas que hace años leímos en el archivo de la casa de Meres, y por su testamento que fue otorgado en la misma prisión, lamentando que lo mismo las cartas que demostraban su prisión en Ceuta, que su testamento se hayan extraviado y no hayamos podido volver a encontrarlas.

Si nos fijamos en la carta de Tineo, y en su estilo excesivamente cauteloso, comprendemos que éste encargó de nuevo a cierta persona para que hiciese llegar a manos del ministro la de un hermano de Argüelles -probablemente el último, llamado José Antonio, que figura como apoderado suyo conjuntamente con don Lope José Argüielles Quiñones, según poder otorgado en Madrid a 26 de enero de 1728 - pero calla el nombre de dicha persona, aunque refiere que logró entregar la carta observando en el Ministro mucha compasión por lo que sufre, y dificultad en promover la indulgencia, palabras estas que no parecen adecuadas al sufrimiento de una simple degradación o rebajamiento en el empleo. Más extrañas nos parecen las palabras que a continuación atribuye al ministro de que el daño no es de Roma, en donde mereció la conducta toda aprobación, pues sabemos bien que no fue así, por la correspondencia con Bentivoglio, aunque no sería imposible que dicha conducta hubiera sido buena en lo que al desempeño de los negocios de su despacho se refiere.

El daño - suponemos que la prisión- según se expresa Tíneo en su carta, «se causó en Madrid de buelta de Andalucía», y «estos extremos - continúa- pueden seruir para exacto examen de lo que se abló, trató, o escribió», añadiendo inmediatamente "que el sexo privilegiado es el que mantiene el encono», para terminar con la advertencia de que con estos datos «discurrirá Vm., si puede sacar algo que yo infiero pudiera 
únicamente redimirnos el que está más lejos, quando las cosas puedan estar sazonadas».

Resulta difícil saber a quién se refiere Tineo cuando dice el que está más lejos, y renunciamos a hacer conjeturas que alargarían esta ya demasiado larga comunicación. Lo que sí hemos de tener en cuenta es el borrador de la contestación de puño y letra del propio Argüelles. Como va copiado en el Apéndice, nos limitaremos a subrayar que la continuación de Argüelles al servicio del Rey después de exonerado y vuelto a España, se prueba por las palabras de este borrador, que aluden a un proyecto que hizo en Cazalla - donde efectivamente se hallaba la Corte en aquel tiempo ${ }^{31}$ - relativo a algo relacionado con la cuestión del trono de Nápoles, en la que tanto empeño puso la reina, cuya persona debe de ser la que se alude en las palabras el sexo privilegiado de la carta de Tineo. Fijo en sus ideas, informó de acuerdo con ellas sin pararse a pensar que pudieran causar algún desagrado.

Argüelles se explica diciendo que no creyó «que pudiese ser culpa querer más desagradar con la verdad, que engañar con la mentira, en asuntos de tan grande importancia», refiriéndose a lo que llama proyecto que había hecho en Cazalla, del que reconoce «pudieran causar algún soberano desdeño". Por lo visto el informe -que Argüelles llama proyecto- debió desagradar a la Reina, partidaria de todos los medios, incluso el de la guerra, por conseguir el trono de Nápoles para su hijo Carlos, y nuestro personaje se explaya en el mencionado borrador diciendo que vistas las cosas que después ocurrieron, lo que "entonces pareció culpa, sería mérito después que los subzesos y nuestra Corte se conformaron a mi profecía». Explica también que a su vuelta y en Madrid, ni su pluma ni su lengua pecaron nada en materia de cosas públicas.

En fin el borrador de la respuesta a Tineo no termina, porque la continuación se hallaba en otro pliego que se perdió. En conclusión lo ocurrido al final de la vida de Argüelles habrá sido que, exonerado de Roma, habrá ocupado cualquier puesto secundario acaso en los asuntos de Estado, de cuyo ministerio continuaba en posesión Orendain, y ya más o menos difamado, y sin modificar su genio atrevido, terminó por caer mal en aquel medio, en el que en aquellos tiempos era fácil ir a parar a un presidio sin causas verdaderamente graves. Ignoramos si la conducta de Argüelles dió algún otro motivo para que mereciese tan duro castigo.

31. Marqués de San Felipe, Comentarios de la guerra de España e historia de su Rey Felipe $V$ el Ánimoso; edic. de la Bibl. de AA. Españoles, Madrid, 1957, pág. 459. 
Creemos que Argüelles murió en Ceuta, en donde, repetimos, otorgó su testamento, que hemos leído hace años y del que solo recordamos su protesta de fe católica, y la afirmación rotunda de que se creía víctima de una injusticia. Y con otros papeles que hemos citado y aprovechado, debió enviarlo a su pariente don Lope José Argüelles - mayorazgo de la Casa de Meres, en cuyo archivo se hayan en su mayor parte- la persona que haya hecho de ejecutor de su última voluntad.

Esta hipótesis de la muerte en el presidio de Ceuta va de acuerdo con aquellas palabras a las que al comienzo de esta comunicación nos referimos, escritas por don Carlos González Posada como recogidas de labios de don José de Ruenes, secretario del Duque de Alba, según las cuales Uriarte Argüelles «al cabo de sus días murió infeliz».

\section{A P E N D l C E}

\section{CARTA AL MARQUES DE LA PAZ DE 21 DE ENERO DE 1730.}

«Excmo. señor. Señor mío, esta Corte concedió a la de Viena la prórroga de la Dézima de los beneficios eclesiásticos, en los estados, que goza en Ytalia, y como aquí se publica, que se hazen allí grandes aparatos, para la guerra, contra el tratado de Seuilla, me parezió impropio, que en esta coiuntura se hiziese tal grazia; por que pareze, que es comenzar esta Corte a declararse parzial de aquélla.

El Cardenal Polignac, Ministro de Francia, que tubo, como yo, la misma notizia, me dixo, que, como amigo de el Papa, y Ministro de un Prínzipe, Aliado de el Rey Cathólico, hauía representado los incombenientes, para que Su Santidad con más premeditazión, suspendiese por aora expedir esta grazia; pero que el Cardenal Secretario de Estado hauía respondido, que hauiendo dado quenta al Papa, se escusó Su Santidad con dezir que no hauía pensado este inconveniente, ni era su ánimo disgustar al Rey Cathólico; pero que hauiendo ya entregado el Breue al Ministro Imperial, no le quedaba otro arvitrio, sin incurrir en maiores incombenientes; haziendo rumor, que perjudicase a las intenziones del Rey Catholico.

En este estado acordé con el mismo Cardenal, que Su Eminencia instase segunda vez al Papa, para que mandase hazer otro Breue, declarando, que en caso de que la Corte Ymperial haga la guerra a España, quedara suspendida esta grazia 
desde el día, que se declare la guerra; porque la Sede Apostólica no puede dar subsidios a un Prínzipe cathólico contra otro.

Hízolo así el Cardenal por medio de otra representazión al Secretario de Estado, quien respondió quedaba en cuidado de dar quenta a el Papa, y avisar su respuesta positiva; pero que temía mucho, que Su Santidad no condescendería a este medio; de que se infiere, que son grandes, muy actibos, y maliziosos los manexos, que se hazen por la Corte Ymperial, cuios ministros duermen aquí con los oxos abiertos, aprouechándose del descuido, y poca aceptazión de nuestro Ministro.

Supe también, que se trata de hazer un quartel, para las tropas Ymperiales en el Estado de la Yglesia, en Bolonia, o Foliño, que es una ciudad buena, en un ve llíssimo valle, entre Loreto y Roma; y aunque se motibó, que es para resguardar los Estados del Sacro Romano Ymperio, en que son incluidos los que la Yglesia goza, se conoze, que el fin no es otro, que ponerlo en un lugar cómodo, para reemplazar los socorros de Nápoles, y Sicilia, a donde se teme, que acoste nuestra Armada.

Avisé las grandes negoziaciones, que hazen aquí los Ministros de Saboya; en que continúan con gran presumpción, y maior fuerza, porque con su dinero, se hizieron dueños de los que mandan a el Papa, no allan en nuestro Ministerio la menor resistenzia: ellos mismos publican, que el Marqués de Breij, Ministro de su Corte en la de Viena, que tubo orden de retírarse, recivió otra, para que permanezca, y que los saboyanos munizionan las Plazas fronterizas a la Franzia: De que se infiere aquí, que las dos Cortes están de acuerdo contra el tratado de Seuilla.

Aquí ha parezido una copia de este tratado, y aunque los hombres de entendimiento la tienen por supuesta, no dexa de contribuir, para que nuestros apasionados se caigan de ánimo; para que esta Corte, en lo universal, mude de sentimiento acia las esperanzas de nuestra dominazión, que hauian conceuido: Maiormente, quando no se vee, que por nuestra parte se haze paso actibo, ni el menor fomento, por que nuestro Ministro prinzipal (cuyo carácter y constituzión tengo explicado) se contenta con retiro de su casa; pasando la vida en lamentaziones: por que no se le paga.

No quisiera, que se lisongease esta corte con los socorros y ofizios de Monseñor Aquaviva, Maiordomo de el Papa; porque ya he insinuado el carácter de este cauallero, y es vien público, que este cargo, y el de Maestro de Cámara los obtubo, por su dinero; y como estos empleos no le han dado la capazidad, y los amigos, que requiere el aire fino de esta Corte, para hazer los negozios, no le tenga ni le tiene ninguno, por apropósito, para encargarse de los nuestros, en tiempo tan crítico, ni su inclinazión a la España tiene más raízes, ni otro objeto, que el interés propio.

V. E. lo haga presente al Rey nuestro señor; para que S. M. sea informado de todo, y me haga justizia de creer con quanto dolor mío, veo, digo, y toco lo que aquí pasa; encogiéndome de ombros a las recombenziones de nuestros amigos. Dios guarde a V. D. muchos años como deseo. Roma Henero 21 de 1730. D. Domingo Arguielles - Excmo. señor Marqués de la Paz.

Los avisos secretos dizen, lo que, más ha de un mes avisé yo del conde de Almenara, y Palma; que se ponía in sacris; por que el señor Emperador solizitaba, 
que recaiese, en él, el capelo por nomina regia, como Rey de España; lo peor es que es cierto, y que a esta intentona se seguirán otras, si el Rey nuestro Amo no pone remedio. Yo avisté a este nuebo sacerdote; porque me parezió atenzión cortesana mientras S. M. no manda otra cosa; porque este cauallero, y el Cardenal Cienfuegos son mis amigos, pero es más mi amiga la lealtad, la razón, la verdad y mi honrra. Véase el capítulo señalado de la gazetilla.

\section{CARTA AL MARQUES DE LA PAZ DEL 23 DE FEBRERO DE 1730.}

«Excmo. señor. Señor mío, aunque el correo de Gauinete, que partió ante ayer llegara prinero a esa Corte, con la notizia de la muerte de el Papa, repito el auiso por el alcance de Franzia a Génova. Murió Su Santidad el martes 21 de el corriente a las tres de la tarde de la repetizión de una fiebre, que le empezó el sáuado antecedente a las diez de la noche, como avisé a V. E. por la posta ordinaria.

Murió también el mismo martes a los ocho de la noche el Cardenal Pipía, religioso Dominico, sardo, Protector de aquel Reyno; y ba creziendo cada día más la epidemia de fiebres, y catarros de que mueren muchos, y de las quatro partes de poblazión, las tres están enfermos, por que la estazión de el tiempo es tan rígida, fría, irregular y constante, que apenas si hay persona, a quien no haya ofendido la pestilenzial influenzia.

El cónclaue próximo, dizen los hombres de juizio, que aunque será embarazoso, por la multitud de pretendientes, no será largo; porque las criaturas de el Papa (que son veinte y seis viuos) no tienen Gefe, Nepote, que haga caueza; las cauezas de otros partidos, no tienen aquella fortaleza de ánimo, que es necesaria, para mantener largo tiempo, una competenzia; con que se puede esperar, que desechos los partidos y desvanezidas las esperanzas propias, se conspire a la uniformidad de hazer uno de los celantes, el que sea más viexo.

No hay aparienzia de que vengan los cardenales ultramontanos de las coronas, menos aquellos de la Germania, de quienes se tiene alguna certidumbre, por las premeditaziones antecedentes; y porque andan muy circunspectos, captelosos, solícitos en las importanzias de Ytalia, desde que empezaron los rumores de la guerra, y no descuirdará, en que se haga de su facción el Papa.

Nuestro Cardenal Ministro, que siempre tiene poca salud, y aora está retirado (poco bueno) puede temerse, que, si entra en cónclaue, experimente algún maior perjuizio con la mutazión de vida, reflexiones, conferenzias, por el trauaxo, y por el incómodo, que en aquellas pequeñas estanzias, se padece mucho: Por lo que siempre será combeniente preuenir alguna disposizión a este Ministerio, para la contingenzia de algún infausto suceso.

Tengo el consuelo, en la presenzia de Dios, y en lo interior de mi conziencia, de aue he dicho la verdad, (como, si estubiera, para morirme) en este asumpto, $\mathrm{v}$ en los demás, que han ocurrido, desde que estoy en Roma: Y aunque Dios, nor sus altíssimos juizios ha permitido, que yo sea tratado, como delinquente, quitándome el empleo, y dexándome sin honor, y sin destino hecho un lastimoso es- 
pectáculo, no por eso mudaré de intenzión, ni dexaré de seruir a S. M. con amor: insinuando todo lo que juzgare digno de su Real notizia, como tantas vezes, en las cartas de V. E. se me ha ordenado.

V. E. lo haga presente a S. M. y síruase fauorezerme, insinuando, que quando se renga alguna considerazión a las cualidades de mi persona, que no son indignas, se tenga algún resguardo al esplendor de las resoluziones de $\mathrm{S}$. $\mathrm{M}$. y al honor de este empleo, sin dexar al reato de malas consequenzias, en lo futuro; para que a los Ministros españoles no se les pierda el respeto, ni ellos dexen de cumplir sus obligaziones por miedo exemplar, de lo que se hizo conmigo. Dios guarde a V. E. muchos años como deseo. Roma febrero 23 de 1730. Don Domingo Argüelles Excmo. Sr. Marqués de la Paz.

\section{CARTA AL MARQUES DE LA PAZ DE 4 DE MARZO DE 1730.}

«Excmo. señor. Señor mío, no llegó nuestra posta, ni aquí hay otras novedades más que las que se expresan en la gazetilla adjunta, y dignas de que S. M. las sepa. Mañana a la noche entran los cardenales en conclaue, menos algunos, que están poco buenos. Nuestro Cardenal Ministro tampoco entrará; porque prosigue a estar enfermo con fiebre, catarro, desbanezimientos de caueza, y le sobreuino a un pie la podagra.

Tengo representado algunas vezes su poca saluz, que le faltan las fuerzas naturales para trauaxar, entrar en discursos, ni hazer serias reflexiones; por lo que se dexa governar de Jabolini, y Mauro; cuia conducta, y mala opinión trahe consecuenzias perjudiziales al ministerio, como se experimenta aora, que todos huien en tratar al cardenal con confianza, y harán Papa a dispecto suio; porque no hay indiuiduo en el Sacro Colegio, a quien no haya disgustado: Asta el Cardenal Polignac se lamenta, porque prefiere sus odios particulares a la causa, y su utilidad pública.

El Marqués de Monteleón, aun no ha venido, y se dize aquí, que quiere venir a jornadas regulares, poco a poco; por que la estazión es rigorosa, tiene muchos años, y no está mui bueno.

El Cardenal Alberoni vino anteayer del Castel Romano y me ratificó oy su propósito de segundar su voto, y sus influenzias las intenziones del Rey nuestro Amo, los órdenes de el Ministro que tenga el secreto; recontóme lo que le pasó con el Cardenal Aquaviua en los dos cónclaues antecedentes; pero que con todo, hauía hecho su deber, en seruicio de S. M., como haría ahora, y que nada sentía tanto, como que se dudase de su constanzia, y se le tubiese por ruin desagradezido. Fortifiquéle en sus buenos pensamientos, y le dixe, que la máxima de una alma grande era, vengarse de los reyes siruiéndolos mexor; que llegaría el caso en que sus Magestades repasando los annales de los seruizios, se manifestarían más grato con aquellos, a quienes los siniestros informes de la emulazión hazen desgraziados. Trátase con confianza con el Cardenal Belluga, que es de una incorruptible fee, y amor a las cosas de nuestra España; pero este purpurado algunas vezes se me lamentó, que la Corte le trata con demasiada independenzia, no, sin remordimiento de su conzienzia, que es delicada. 
Dícese aquí, que las dos coronas, España y Franzia hazen sus manexos, por que no se haga Papa ningún Toscano, por lo que pueda contrabenir al establezimiento de el señor Ynfante don Carlos: supongo, que esta voz es maliziosa, y tiene poquíssimo fundamento; pero, si tubiera alguno, sería muy impropio; porque toda Toscana, pleue y nobleza, desea la dominazión de el señor Don Carlos, por sus derechos, y por lo que les importa el comerzio, y dependenzia con la España; y yo puedo certificar de los cardenales, que hay aquí, que siempre los he oído con este sentimiento; vien que quisieran, que fuera por tratado; porque la Toscana no es país de poder sufrir guerra; pendiente de sus intereses, y sus frutos, más de el comerzio, y la industria, que de la substancia. Dios guarde a V. E. muchos años que deseo. Roma marzo 4 de 1730. D. Domingo Argüelles - Excmo. Señor Marqués de la Paz.

\section{CARTA DEL CARDENAL BELLUGA DE 16 DE MARZO DE 1730.}

"Eminentíssimo señor. Mui señor mío, asta ayer, por aquí fuera la voz pública a fauor del Cardenal Ymperiali; pero ayer vaxó mucho, diziéndose, que se hauía varaxado este partido; por que nuestro Cardenal Ministro fomentado de algunos, y de su particular odio, clamaba, como una Aguila en nombre de nuestra España. Dícese también, que Vuestra Eminencia, y el Cardenal de Polignac le resisten fuertíssimamente, diziendo, que no tiene la exclusiba; cuya espezie sirue de grandíssimo consuelo a todo Roma, que desea la elección de Ymperiali, como la más propia. V. Emma. mexor que yo saue, que el Rey nuestro Amo no tiene interés, ni respeto más priuilegiado, que intervenir a que se haga lo más justo; por que para España todo venemérito es bueno. Saue V. Emma. también, que hay peligro en la tardanza; por que si se desmenbra este partido, los imperiales tedescos, y dependientes, (que son 22 votos seguros) harán otro a modo suio, que nos cause maior perjuizio.

Dícese, que vienen de Franzia Ruan, y Visie, cuia notizia también es considerable al Cardenal de Polignac, para temer el peligro en la tardanza; pero que no hará Su Eminencia aquella figura, que haze aora, ni tendrá toda la gloria, que le rinde Roma, y le rendirá todo el mundo porque fauorece una elección tan justa. Dígaselo, por Dios V. Emma., ganemos tiempo, hágase la justizia, antes que el Diablo meta la mano en la masa.

Acuérdese V. Emma. con prizipalíssimo cuidado de interesarse con nuestros amigos, y aliados, para pactar con el Papa futuro que tome la garantía con nuestros Reyes, Ymperio, y Franzia, para asegurar la subcesión de Toscana, Parma, y Pla. senzia, sin venir a los infaustos subcesos de una guerra, en que se derramará tanta sangre christiana; por que sobre este empeño el primer paso del ministerio Apostólico, será cosa más estimable a los Reyes, al Cardenal de Fleuri, a España, Franzia, y aún a el Ymperio mismo. Los Cardenales Polignac, Alberoni, y Cienfuegos segundarán los pasos de V. Emma. aiudándole a tan santa obra.

Monteleón no vino, ni se saue quando llega. Tendrá ciudado de avisar a V. Emma. lo que ocurra; pero est periculum in mora. Dios guarde a V. Emma. muchos años que deseo. Roma Marzo 16 de 1730 - Eminentísimo señor Cardenal Belluga. 


\section{CARTA AL MARQUES DE LA PAZ DE 18 DE MARZO DE 1730.}

Excmo. señor. Señor mío, por los auisos, que salen del Cónclaue, se saue aquí, que crezen los manexos, y los regiros de algunos Albanistas, y de los Benedictinos, fomentados de los ministros de Saboya, que también quieren hazer su figura; pero el partido nemini, que es el de Ymperiali, se mantiene firme en 21 votos, siempre fixos; sin que los rumores de nuestro cardenal Ministro, haian producido, más, que suspender el acto formal de la elección, asta que buelba de esa Corte el Co. rreo, que llebó la notizia de la muerte del Papa; por si trahe alguna instrucción, o orden positiba. Y aunque algunos Cardenales criticaron al cardenal Cienfuegos, porque hauía dado el consentimiento, respondió que era muy justo tener con la Magestad de el Rey Cathólico, este respeto. Vien, que en esta condescendenzia se incluie el interés propio de que lleguen los cardenales Ymperiales, para engrosar su partido.

Se saue también, que nuestro Cardenal Ministro se mantiene en su celda, poco bueno, sin entrar a los escrutinios, y que van cada día los dos Cardenales enfermeros, quatro conclauistas, y el Maestro de ceremonias a tomarle el voto; con que siempre, podemos esperar poquíssimo prouecho de su influxo. $Y$ es vien repacanoniza la parte más sana del Sacro Colegio, y la voz pública de esta Corte, compuesta de todas las naziones del mundo; por que sobre ser este purpurado amantíssimo de la nazión española, de que yo tengo experienzia práctica, no pareze razón, conbenienzia ni política hazer enemigo nuestro, un hombre, que, aunque no sea Papa, tiene siempre gran autoridad con la Sede Apostólica.

Puede temerse, que, si este partido se desbarata, se forme otro, por la fuerza y el manexn de los cardenales ymperiales, de sus parziales, y sus dependientes, a los quales corre ya la voz, que se unirán los quatro Cardenales florentinos, por la correspondezia intima entre las dos Cortes, y en este caso, o harán un Papa inútil, como el pasado, o harán otro cuias operaziones pendan del arbitrio del Ymperio.

Dízese aquí, que los florentinos trauaxan con gran diligenzia a restablecer su govierno antiguo, en calidad de República, baxo la protección de el Ymperio, y que mente séptimo, y del señor Emperador Carlos Quinto, así también, quieren resta blecer su libertad de acuerdo de el señor Emperador actual, y el Papa Futuro; cuia negoziazión se fabrica en Roma, sin que ninguno, por nuestra parte, haga resistenzia, ni hable palabra.

También se dize, que el Príncipe Eug enio viene de Vicario General de Ytalia, que pasa a Turín, y que fixará, después, su residencia en la ciudad de Bolonia, para estar en lugar proporzionado a las expediziones de la guerra; y que para que no se moleste al Estado de el Papa, pasarán por Trieste las tropas, para fortificar Nápoles y Sicilia: De que infieren algunos políticos, que puede hauer algún manexo oculto, entre la Sede Apostólica, el señor Duque de Saboya, y el Ymperio, a fauor de el mismo Prínzipe Eugenio, y de la línea de su hermano.

Se espera aquí, por embaxador extraordinario de el Ymperio al Conde Colalto, Consexero de Estado, natural de Frioli, en los estados de Venezia, que también tiene feudos en la Ungría y también se espera que lleguen los cardenales Ymperiales, y los de Ruan, y Visie, en la semana próxima; con que se puede temer, que, sino se haze el Papa luego, crezerán los embarazos y será el Cónclaue mui largo. 
Dios guarde a V. E. muchos años como deseo. Roma marzo 18 de 1730 . D. Domingo Argüelles. -- Excmo. señor Marqués de la Paz.

\section{CARTA AL CARDENAL BELLUGA DE 23 DE MARZO DE 1730.}

\section{Emmo. señor.}

Mui señor mío, la exclusiba que se dize, dió el señor Cardenal de Bentivoglio a el señor Cardenal Ymperiali, en nombre de nuestra España, conzilió contra nosotros la abominazión universal de toda Roma; y como todos sauen, que el Rey nuestro Amo es un Prínzipe escrupuloso, lleno de piedad, y de justizia, admiran mucho, que haia tomado una tan gravíssima culpa sobre su delicada concienzia.

Combienen todos, en que el Cardenal Bentivoglio, prebentivamente, habrá sorprehendido las rectas intenziones de S. M. con falsas imposturas, contra este dignísimo purpurado, a quien califica la parte más sana del Sacro Colegio, la voz pública de esta Corte, compuesta de todas las naziones de el mundo, y la experienzia práctica en más de cincuenta años de Ministerios públicos, en que resplandezieron su prudenzia, su doctrina, su piedad, y su desinterés, que es la virtud más difícil de encontrarse en los que siguen esta curia.

Yo, que conozco el genio de el Rey mi Amo, las cáualas y entrigas de nuestra Corte, me atrebo a asegurar, que o no tubo parte en esta exclusiba, o si la tubo, la revocará, quando tenga informes ciertos de las calidades de el personage de quien se trata; y sobre este conocimiento escriuí ayer por la posta de Franzia, largo, claro, combiniente, de tinta dina; sin temer el sacrifizio, quando se trata de la materia más crítica, que puede ofrezerse en la gran serie de el Reynado de un Rey Cathólico.

He reparado, con seria reflexión, que la carta en que funda la exclusiba es de 9 de noviembre quando nuestra Corte estaba en disgusto con todo el mundo, recelosa de lo de Viena en nuebos tratados con las de Franzia, Olanda, Ynglaterra, que se concluieron tres meses después en Seuilla; y no era extraño que, aunque, entonzes hubiese alguna sospecha, para dar esta exclusiba, las varias circusntanzias, que sobre vinieron después, sean causa, para revocarla; expezialmente, si la Franzia está a fauor de Ymperiali, como se publica.

V. Ilma. con su christiano celo, y sobre la experienzia, que tiene de las intenziones de el Rey, en los cóncalues antecedentes, puede remediar este gran daño, uniéndose con los señores Cardenales de Polignac (si fuese seguro) y los otros, que componen este partido, para pedir, que se suspenda la elección que se despache correo a España, a toda diligenzia, con dos cartas a Rey, y Reyna, cometidas al Nunzio para que soto las penas, y maldizión de la Yglesia, las ponga en manos propias, y saque respuestas positibas: la misma diligenzia se puede hazer en la Corte de Franzia, para que concurra con su influxo, o a lo menos no lo rre sista; que, si se hiziere así, yo prometo, con mi caueza, que se rebocará la exclusiba y tendremos la felizidad de ver en la Sede Apostólica el hombre que tanto se nezesita, y se desea. 
V. Ilma. ponga espezialíssimo cuidado en reconozer la intenzión de el señor Po lignac, de quien yo dudo, y si le alla fuerte en este partido léale V. Ilma. esta mi carta; pero si no quémela $V$. Ilma. Lo mismo suplico a V. Ilma. que haga con nuestro Cardenal, el señor Alberoni, nuestro amigo el señor Coradini, y con los que V. Ilma. juzgare conbiniente para este justo intento, de que Dios se dará por vien seruido.

Señor, las grandes resoluziones quieren grande ánimo, et nullum magnum remedium, sine aliquo perjuditio; trátase de la cosa más importante, que hai en la vida humana, para los verdaderos hixos de la Yglesia, pro iustitia agonitare; si se deshaze este partido, acaso, conciliaremos contra nosotros la ira de Dios, y permitirá Su Magestad que se haga uno, peor que el pasado, o otro, cuias operaziones pendan absolutamente de el Ymperio, y nos haga pagar nuestro pecado.

Esta exclusiba, si se consiente, correrá con grande dcshonor nuestro, por todas las Cortes de Europa; el Rey que lee todas las gazetas cada semana verá nuestro improperio y su injustizia; reflexionará con su escrúpulo, y remordimientos; y no será extraño que enterado de la malignidad de este caso, se prezipite y huia otra vez al retiro del desierto.

Por Dios suplico a V. Ilma. que refleione este punto, no quede sobre nosotros esta fea mancha, por el capricho, odio particular, rencoroso, de un Ministro forastero, que sacrifica nuestros intereses, nuestra honra, y la conzienzia de un Rey candidíssimo, por su venganza. Dios guarde a V. Ilma. muchos años que deseo. Roma marzo 23 de 1730. D. Domingo Arguielles - Emmo. señor Cardenal Belluga.

\section{CARTA AL MARQUES DE LA PAZ DE 20 DE ABRIL DE 1730.}

Señor mío, el sáuado a la noche un alto manexo que hizo el Cardenal Rufo, para obtener el Pontificado, que se publicaría al día siguiente, si no se hubiera descubierto. Dízese, que aiudado del Cardenal Cienfuegos, preparó el ánimo de los franceses; prometiendo el capelo, para el Arzobispo de París, de grazia, sin nomina regia, y al Cardenal Bentivollo, que ya era su amigo, otro para Monseñor Aquaviua; y que a los Cardenales Benedictinos les fue prometiendo, según la pretensión de cada uno, asegurando a todos, que no innobaría en las cosas de el próximo Pontificado.

Subcedió, que confiándose dos, uno de el otro, hallaron que hauía prometido a ambos un mismo destino. Dícese que resentidos descubrieron el negoziado al Cardenal Buencompaño, Primo de Rufo, alzaron el grito diziendo, que no combenía exaltar un hombre de genio fuerte, alto, que hauía incurrido en este prevaricato, y que antes de sentarse en la silla, pactaba, repartiendo las dignidades de la Yglesia, que es una espezie expresa de simonía; y que siendo el mayor cuidado del Sacro Colegio remeter en orden los excesos, e impropiedades de el próximo Pontificado, quedarían vanas, inútiles sus providenzias, si el Papa futuro se oponía a este proiecto.

Dízese, que se interceptaron ciertos villetes entre los Cardenales Coscia y Rufo, que hablaban de este negoziado; y con efecto se experimentó, que, siendo caput 
de orden Rufo, dio la posesión de chierico de Cámara a Monseñor Casoni, y se la dió también a Monseñor Vidoni de la Presidenzia que hauía suspendido el Cardenal Camarlengo; por que havían obtenido estos empleos, por medios impropios; con que juntándose unos, y otros casos, formaron concepto de que no combenía exaltar a Rufo, desbarataron su partido, y no sé si diga la reputazión en que estaba con universal buen concepto.

De este subceso, y la intimidad, que se publica entre Cienfuegos, y Bentivollo (que no la juzgo sincera) puede inferirse lo que en mis antecedentes tengo dicho, que los Alemanes, y sus dependientes, no piensan a fauor de Ymperiali con candor de ánimo, que en darle nuestra immadura exclusiva hemos hecho del negozio de el Ymperio, quedando sus ministros con el mérito, y nosotros con el oprobio.

Fortificado mi dictamen, porque oigo a los Ymperiales lamentarse de la demasiada bondad de Cienfuegos, en el trato íntimo con Bentivollo, a quien llaman inútil porque, haviendo ya disparado la exclusiba, se quedó con poca o ninguna fuerza: ellos mismos publican que Bentivollo aiudaría a Rufo, sin impulso extraño; más, que su interés propio, y que entre Cienfuegos e Ymperiali hai alguna disonancia de persona a persona; pero yo que conozco a Cienfuegos, no creo, que su bondad sea tanta, que proceda, en estos extremos, sin alguna máxima oculta, ni que prefiera las obligaziones de su cargo a la disonanzia persona, que no permitirían los Alemanes, que tiene consigo.

También me fortifico, porque aún dura el displazer entre Polignac y Bentivollo, y se dize, que, aunque el segundo solizitó la mediazión de Ruhan, para sincerarse con el primero, respondió Ruhan, que no podía entrar en las cosas de Bentivollo, ni dexar de segundar la operazión de Polignac ministro de su Corona, cuia conducta le fue aprouada; maiormente, quando Polignac responde, traten a Bentivollo, y aconséxenme después, que es lo que a otros mediadores dize: Conque no puedo persuadirme, que, si los franzeses quieren a Ymperiali, dexen de conozer, que es fraudulosa la condescendenzia de Cienfuegos con nuestra exclusiba, y que en este trato íntimo de Bentivollo es eómplize o engañado,

V. E. lo haga presente al Rey, porque, aunque de los avisos, que vienen del cónclaue no se puede hazer sólido fundamento, siempre combiene, que S. M. sepa lo que se habla, para ser informado de todo, que es la intenzión con que escriuo. Dios guarde a V. E. muchos años, como deseo. Roma, abril 20 de 1730. D. Domingo Argüielles. - Excmo. señor Marqués de la Paz.

\section{CARTA AL MARQUES DE LA PAZ DE 22 DE ABRIL DE 1730.}

Excmo, señor. Señor mío, en la posta de ayer no tube carta de V. E. ni aquí hai novedad espezial en las cosas públicas, desde ante ayer que escriuí, por el alcanze de Francia lo que ocurría; porque, aunque continúan los manexos, y los regiros, en el cónclaue, se cree, que no se haga cosa positiba, asta que buelban los correos de esa Corte, por la esperanza, que tiene la gente buena, de que la Magestad de el Rey nuestro señor reuocara a la exclusiba, sobre que he escrito ya mi sentimiento. 
Con la ocasión de hauer remitido a don Santiago Riol un Real despacho, presentazión del priorato de Ronzesvalles, con sobre escrito al Cardenal Bentivollo, considerándome en camino, aunque yo le hauía escrito lo contrario, llegó el caso do disputarme los frutos de la expedizión, detenida por sede vacante como preuine a V. E. en mi carta de 2 de marzo; porque Saporito, Exabolini y Mauro (que todos tres tienen en la caueza la Agenzia de España, antes que yo biniese a Roma) manexan con el Cardenal hazerme este agrauio, haziendo, que el expedizionero re gio no me socorra, en quenta desde producto.

Ynformé al Marqués de Monteleón lo que pasaba, para que poniéndose de acuerdo con el Cardenal, arreglasen los dos esta diferenzia y aunque el Marqués se persuadió fázilmente de mi razón, que es tan clara, quiso que la pusiese por escrito, para pasársela original a su eminenzia, y no intriegarse en cosa, que pueda tener conexión con el ministerio de Roma; por que conoze el genio, y saue andar el paso de el mundo, sin embarazarse en remediarlo.

Harélo así, y remitiré a V. E. copia, quando avisare la determinazión, que no será muy buena; porque comprometido el Cardenal en el arbitrio se conformará con su instanzia, así como por el impulso de ellos conspiró a mi ruina, sin que yo le haia dado la menor causa, como es vien notorio a toda Ronia, y como reconozerá V. E., si seriamente reflexiona los casos, y cosas, en que se haia lamentado de mi Su Eminenzia, no más que por la simple aprensión, en que le han puesto esta gente maligna codiziosa.

No puedo aquietar la admirazión, de que, hauiendo escrito Su Eminenzia a mi fauor tantas alabanzas, y hauiendo yo estado con la maior venerazión a su persona, y su grado, sin dexar de obedezerle en quanto quiso, se haia puesto en una aversión contra mí, que no se contente con hauerme quitado el empleo, impedir que me pagase el Director de la posta el atraso de mi sueldo, sino quitarme también el tratamiento y honores de Agente, e impedirme aora los frutos de la expedizión, que el Rey me consigna por parte de alimentos de su real título y otras injurias, que no digo, por que no parezca que el sentimiento me haze torzer la razón hazia el agrauio.

Ni puedo comprender, que S. M. por unas vagatelas, que son ridículas haia condescendido en deponerme, de un cargo honorífico, que es tan respetable, en este thatro universal del mundo; sin tener resguardo al honor del mismo empleo, a las circunstanzias de mi persona, a las consecuenzias de su Real Seruizio y a la disonanzia, que haze a todos, de que, sin causa, se quite al ministro español el empleo, y la honra; solo por condescender al equivocado concepto de el ministro forastero, en que ni aún él mismo tiene más culpa, que la de dexarse conduzir de estos tres hombres, cuia dañada intenzión es vien conocida.

Yo suplico a V. E. me haga honor de repasar estas circunstanzias, considerando lo que yo pierdo, la repugnanzia con que vine aquí, sobre la experienzia de el peligro, los gastos de más de dos mil doblones que he hecho, las incomodidades de un camino de quinientas leguas en la rigurosa estazión del Ybierno; que dexé la Diputazión de el Prinzipado de Asturias, mi Patria, que me frutaba seiszientos doblones cada año, y de grandíssima honrra; que vendí mis libros, y los muebles de mi casa, que tenía en Madrid muy vien puesta; que por grazia de Dios soy un hombre de honrra con profesión, y reglas generales, para seruir a S. M. con honor 
en cualquier línea, y últimamente, que seruí a S. M. y a la nazión aquí con gran decoro, sin perder negozio alguno, guardando a el Papa, y sus ministros el debido respeto.

$\mathrm{Y}$ aunque he representado a V. E. esto mismo en diferentes ocasiones, siempre considero necesario repetirlo, por que, aunque yo hubiera tenido alguna parte en el ridículo embarazo de mis criados con los esvirros, en que el Cardenal me hizo el asesinato, y después el proceso; no es causa vastante, para deshazer, y arruinar un hombre de estas circunstanzias, que llegó a este empleo, por sus pasos contados, a costa de muchos de estudio, trabaxos, y dinero; y que puede, y debe llegar a otros maiores, si la piedad del Rey se digna darle ocasiones, en que haga maior, y más público su mérito.

V. E. haga presente al Rey, para que S. M. se sirua resoluer, como en mis antecedentes tengo pedido; para que yo no salga de aquí con deshonor, sin destino propio, y sin cobrar el sueldo, y emolumentos, que tengo seruido. Dios guarde a V. E. muchos años como deseo. Roma abril 22 de 1730. D. Domingo Argüelles - Excmo. señor Marqués de la Paz.

\section{CARTA DE DON JOSEPH ANTONIO DE TINEO Y RESPUESTA DE DON DOMINGO (MAYO DE 1732).}

Amigo y señor: Quien tubo mi encargo nuebamente, para facilitar que la del hermano llegase a manos del Ministro, me auisa hauerse entregado, y que se solizitara si pudiere tener respuesta. Dize también que se obseruó en el Ministro mucha compasión de lo que se sufre, y dificultad en promover la indulgenzia. Que el daño no es de Roma, en donde mereció la conducta, toda aprouación, que se causó en Madrid de Buelta de Andalucía, cuyos puntos deben seruir para exacto examen de lo que se abló, trató, o escriuió. Que el sexo priuilegiado es el que mantiene el encono. Con que de este apuntamiento dscurrirá Vm., si puede sacar algo, que yo infiero pudiere únicamente redimirnos el que está más lejos, quando las cosas puedan estar sazonadas.

Deuo salir en principios de la siguiente semana a Palencia a reuisar aquellos Ymbálidos, y formar de ellos dos vatallones en el nuebo pie que se ha resuelto siruan, no sé lo que me detendrá esta comisión; pero quando me restituya auisaré, y las cartas que vengan en el tiempo de su ausenzia, se recoxerán como aora. Incluyo la adjunta, y repito a V., mi amistad y afecto con el que deseo le guarde Dios muchos años. Madrid 20 de mayo de 1732. Besa la mano de Vm. su más seruidor y seguro amigo Joseph Antonio de Thineo -rubricado-.

(En el mismo papel a continuación y sin el margen de la carta, va lo que sigue de puño de D. Domingo Argüielles):

"Mi respuesta" - «Amigo y señor, por la de Vm. de 20 de maio, conozco, que el nuebamente encargado se azercó al encanto, más que su antezesor en año y medio; Y si la compasión que se obserbó en el ministro, fue verdadera, será remordimiento de conziencia, que acusa la injustizia; por que sería vobería creer del enemigo, que haga grazia. 
La conducta mía, que fue agradable a Roma, y a las otras Cortes, que hilan más delgado, que la nuestra, mal pudiera reprobarse, quando no hize paso que no fuese meritorio, y reziuí gracias, por cada uno, pero no entiendo, como componen hauer merezido toda aprobazión la conducta en Roma, y auerme quitado el empleo, con tanto escándalo; dándome, después, otro destino, tan impropio, que fue más vergonzoso desaire, que el primero.

La ingenua libertad christiana de dictámenes, mis auisos, y mis pronósticos, sobre la guerra de Ytalia, y últimamente el proiecto, que hize en Cazalla, en virtud de la obedienzia, pudieran causar algún soberano desdeño, en el sexo priuilegiado; porque me oponía a un engaño, que fundaba en el gasto, y se apoyaba, con la opinión de los que ocupaban más alto lugar en el Real agrado: Pero como me allé obligado a decir mi sentir, no entendí, que pudiese ser culpa, querer más desagradar, con la verdad, que engañar con la mentira, en asuntos de tan graue importanzia; Y aunque rezelé, quise más exponerme a padezer una pena temporal, que la eterna; pero, si entonzes parezió culpa, sería mérito después que los subcesos, y nuestra Corte se conformaron a mi profezía; consiguiéndose, por los medios pazíficos, que propuse, la quieta posesión de la tierra prometida; que no se hubiera jamás conseguido, en la otra forma, aunque se arruinase España, de que no lloraría Franzia ni Ynglaterra.

En Madrid, a mi vuelta de Andalucía, protexto ante Dios, que no pegué, con la imaginazión, la pluma ni la lengua; porque aunque me visitaron algunos grandes y ministros afectos míos, no exzedió nuestro trato de las zeremonias cortesanas, ni tocamos la más innozente murmurazión de cosas públicas ni secretas.

Ni io, desde allí, escriuí, más, que al embaxador de Franzia, y otros amigos, el ordinario cumplimiento de rezién llegado.

Visitóme el duque de Ormón, por orden que tubo de su Amo el Rey Jacobo de Ynglaterra, que está en Roma; diziéndome Su Magestad quanto le hauían sido agradables mis atenziones, y quanto se hauia inclinado su Real venigno genio, a fauorecer el mío. Paguéle la visita, y hauiéndome combidado a comer en otro día, tubo un espléndido banquete, a que concurrieron los caualleros Yngleses de su séquito, que están al seruicio del Rey mi Amo". 